As was to be expected, the general discussions provided evidence of the need for a wide view of the problems of Nature protection. Thus, a remark made in submitting the British proposals that Nature protection meant not only the preservation of communities of plant and animal and the amenities, but might also affect man's welfare and even his existence, was expanded by Mr. G. Brewer, of the Now York Zoological Society, with specific examples from the American continent which illustrated what may be termed the global view, and Governor G. C. Guibet, of the French Colonial Service, who stressed the political aspects.

The wisdom of postponing discussion of controversial matters until the end of the meeting gradually became obvious, and what amounted to a wellorganised opposition to the 'obstructional' attitude attributed to the British delegates was so far converted by the realization that all had the same object in view and that no time had been lost during the Conference, that little difficulty was found in making the few adjustments necessary for complete agreement. The proceedings on the last morning were soon concluded. It was unanimously agreed that the Swiss League should continue to act as the agent for the provisional organisation and to carry out all necessary business as provided for by the provisional constitution. The League shall immediately send the draft constitution to the United Nations Educational, Scientific and Cultural Organisation asking for it to be transmitted to all Governments inviting them to communicate to the Organisation whether they can accept the draft constitution with or without amendments. The Organisation is requested to convene a Congress at Paris in July 1948 to discuss and finally accept a constitution based on the draft constitution. A request is to be sent to the Swiss Government asking that it shall communicate with the signatories of the 1913 Convention asking for its cancellation.

All that remained was for the Conference to pass a well-earned vote of thanks to Dr. Bernard for the excellent way in which he had presided, and to the Swiss League and its officers for their hospitality, initiative and labours.

Further matters call for comment. An international committee was formed to consider the various terms used in Nature protection, to collate national usages and formulate an international nomenclature.

Dr. R. Videsott gave an account of the Italian National Park at Gran Paradiso. At present there are nine hundred chamois and six hundred ibex protected by sixty gamekeepers. Owing to lack of funds, the Ministry of Agriculture and Forestry has had to discontinue the maintenance of the gamekeepers, and unless private subscriptions are available this most important European game reserve will be denuded of its treasures.

One of the societies sending delegates to the Conference was the Nederlandse Jengdbond voor Naturstudi, a youth organisation with four thousand members between the ages of twelve and twentythree, which has the protection of Nature as one of its main aims. It has a central office and eighty-five subsidiary centres, and a very efficient organisation with camps, lectures and its own periodical.

At the end of the Conference the majority of the delegates spent several days visiting the Swiss National Park. To their dismay they learned that there is a proposed scheme for a hydro-electric installation which will dam up the streams in the upper reaches of the Park and inevitably convert this famous forest region into a stony wilderness. Swiss naturalists are not alone in asking cui bono ? They saved the Lac de Sils, menaced by commercial development, after indemnifying the local communes by the profits from the unrestricted sale of chocolate medals-chocolate then being rationedand had sufficient funds over to construct a research laboratory. May the public interest again be successfully brought to bear, for the preservation of its National Park means not only the retention of a beauty spot with its fauna and flora, but also the continuance of a living laboratory rich with promise of data valuable for the proper development of the country's forests.

J. RamsBotтoM

\section{MICROSEISMS AND ATMOSPHERIC OSCILLATIONS}

\section{BY ERNEST TILLOTSON}

$T$ HE surface of the earth is in constant movement with amplitudes of a few thousandths of a millimetre, and this movement is picked up and registered by instruments set up to record the passage of waves caused by earthquakes. An earthquake starts from a definite focus, but a microseism is any ground movement which has not been started by an earthquake. Bertelli, who first used the name 'microseism' in 1878 , probably intended the name to cover only those waves of $5 \pm 2$ sec. period which were somewhat regular in character and which, beginning with small amplitudes, grew in intensity and then died out in a length of time up to a few days.

The Japanese at one time considered microseisms to be stationary waves; but J.J. Shaw and others showed that they are progressive waves. They have a velocity of $2 \cdot 5-3 \cdot 5 \mathrm{~km}$. $/ \mathrm{sec}$. Lee did a considerable amount of work on microseisms and came to the conclusion that they were largely composed of Rayleigh waves. He then attempted to use this fact ("On the Direction of Approach of Microseismic Waves", Proc. Roy. Soc. London, A, 886, $183 ;$ 1935) to find the source of microseismic waves. To gat the direction from which the microseismic waves were approaching the observatory, Lee assumed them to be Rayleigh waves and noted the phase differences on the threecomponent seismographs. Thus if Rayleigh waves were approaching from the north, the sequence of ground movement should be up north down south; if from the south, the sequence should be up south down north, and so on. Lee had some difficulty, as he found the phase differences between the components of the microseisms to be variable, although the values appropriate to the general direction of approach were dominant. He used the dominant direction so obtained. His difficulties were probably due to the approaching microseisms not being completely Rayleigh waves, as there was some motion across the direction of propagation. Rayleigh waves were, however, dominant.

On account of the exigencies of war service, this work was not continued; but Lee and also J. J. Shaw were definitely of the opinion that the character of microseisms was influenced by geological structure. Banerji and Zanon thought not. Geological faults hinder the passage of microseisms in the Caribbean, 
and damp out microseisms. Since microseisms have a wave-length of $12-25 \mathrm{~km}$., it is thought that the faults must go a considerable depth. The same microseismic movement raroly extends over a whole continent, and always appears to have something to do with atmospheric disturbances. Lee noticed that microseisms had larger amplitudes and longor,periods in winter than in summer in the British Isles. In 1937, Baird at Christchurch, New Zealand, experimented with a modified condenser microphone and obtained records of air-pressure pulsations with a range of $0.002 \mathrm{~mm}$. of mercury pressure which always appeared to lag behind the microseisms. The air-pressure pulsations agreed in period with the concurrent microseisms and varied directly in size with them. At Samoa, microseisms seemed closely related to synoptic charts. Baird suggested a study of convection cells in air of adiabatic or superadiabatic lapse-rate. These somotimes provide enormous quantities of energy.

Microseisms may begin in a number of ways, and up to the present time the following have been considered most common. E. Weichert in 1904 noticed the similarity of the characteristics of microseisms and sea waves, especially the close agreement between the periods, and suggested that microseisms were caused by the impact of sea waves on rock-bound coasts. Gutenberg followed this up by suggesting that the microseisms of north-west Europe were caused by the beating of the waves on the Norwegian const, and the microseisms of western America by the beating of the waves on the rocky Canadian Pacific coast. Gherzi and Banerji noticed that large microseisms often occurred when a storm was far out at sea and not near the coast, Gherzi noting that large microseisms at Zi-ka-wei occurred when there were cyclones in the surrounding regions, but not when the sea waves were caused by monsoons. It has been suggested by Gherzi and Bradford that microseisms may be caused by atmospheric oscillations or 'pumping' near the centre of a cyclone. Banerji noticed that the microseisms were great when a storm was approaching India over the sea, but that they were insignificantly small when the storm was over the land. All cyclones do not produce the same intensity of microseismic disturbance, as was pointed out by Lee when he direated attention to the synoptic charts of the British Isles for $7 \mathrm{hr}$. on January 3, 1930, and $18 \mathrm{hr}$. on January 11, 1930. These are very similar, except that the barometric gradients are steeper on the former date, Microseisms on both occasions apparently started at the low-pressure area between Iceland and Scotland, but tho microseismic amplitudes on the latter date were nearly treble those on the former date in north-west Europe. Ramirez found that group microseisms of $4-6$ sec. period arrived at St. Iouis whenever a hurricane or an intense extratropical cyclone moved over deop water at sea. During 1938 the direction of approach was never from a storm over land. The Now England hurricane of September 1938 caused microseisms while it was at sea, but not when it was over land. The direction of approach was always from the centre of the hurricane and not from the surf on the coastline. Suzuki and Omori used three 'leaking microbarographs' at three stations in Japan four miles apart, and found air oscillations of wave-lengths 13$25 \mathrm{~km}$. with velocity $20-50$ metres per sec. and periods $6-11 \mathrm{~min}$. at levels $3-8 \mathrm{~km}$.

Since microseisms appeared to originate in areas of low barometric pressure at sea, the U.S. Navy decided in 1943 to attempt to track such storms in the Caribbean Sea by means of microsoisms, using the tripartite station method with precisely simultaneous timing suggested by $J$. J. Shaw in England in 1920, and used on group microseisms of 4-6 sec. period by Ramirez, with an extra station at St. Louis, U.S.A., in 1940. This method has the advantage of being independent of the type of waves, and makes the seismograph a meteorological instrument. The U.S. Navy placed the project in the hands of Lieut.Commander Marion H. Gilmore, who set up three such stations at Guantanamo Bay, Cuba; San Juan, Puerto Rico; and Richmond, Florida. Each tripartite station gave the direction of the storm, and by means of the three stations the position of the storm centre was obtained with some certainty and its path traced as the storm moved. Each tripartite station consisted of three seismographs orientated in the same direction, and one in each of three vaults at the vertices of an equilateral triangle of $8,000 \mathrm{ft}$. side. The seismometers were of the MacelwaneSprengnether type, each consisting of a boom assembly, a coil magnetic unit and the damping magnetic unit; and the maximum synchronous magnification of the instruments when operating at a period of 6 sec. was about 2,500. For the three seismometers there was a central recorder and simultaneous timing. This made for convenience of reading, as quick reading was essential. The cost of the whole project was about $£ 19,000$, which is small compared with the damage done by one hurricane such as that of Septernber 1938, which caused property damage of some $£ 75,000,000$. With this success in mind, the U.S. Coast and Geodetic Survey is at present conducting an intense world-wide research programme on microseismic disturbances.

Following the work of Miche in 1944 the British Admiralty Research Laboratory has been doing important work on the connexion between sea waves and microseisms.

The discussion on atmospheric oscillations at the Royal Astronomical Society on January 24 (see Nature, March 15, p. 357) was concerned with the earth's atmospheric tide caused by the moon, and solar daily oscillations in the earth's atmosphere; it did not throw any light on atmospheric oscillations which would be likely to cause microseisms.

\section{OBITUARIES}

\section{Mr. R. I. Pocock, F.R.S.}

Mr. R. I. Pocock, superintendent of the Zoological Society's ('rardens during 1904-23, died suddenly at his home in London on August 9 at the age of eighty-four. Ho had boen working as usual at the British Museum (Natural History) only tho previous day.

Reginald Innes Pocock was born on March 4, 1863, at Clifton, Bristol, and was the fourth son of the Rev. Nicholas Pocock. He was oducated at St. Edward's School, Oxford, Frank Townsend's School, Clifton, and University College, Bristol. In 1885 he joined the staff of the British Museum (Natural History) and was placed in charge of the Arachnida and Myriopoda. He soon became well known in these groups as a result of numerous publications, including the volume on Arachnida in the "Fauna of British India", and on Chilopoda and Diplopoda in the "Biologia Centrali-Americana". He also con- 